\title{
LEGAL MATERIALS
}




\title{
Participation In Multilateral Treaties ${ }^{1}$
}

\author{
EDITORIAL INTRODUCTION
}

This section records the participation of Asian states in open multilateral lawmaking treaties which mostly aim at world-wide adherence. It updates the treaty sections of earlier Volumes until 31 December 2012. New data are preceded by a reference to the most recent previous entry in the multilateral treaties section of the Asian Yearbook of International Law. In case no new data are available, the title of the treaty is listed with a reference to the last Volume containing data on the treaty involved. For the purpose of this section, states broadly situated west of Iran, north of Mongolia, east of Papua New Guinea and south of Indonesia will not be covered.

\section{NOTE:}

- Where no other reference to specific sources is made, data were derived from Multilateral Treaties Deposited with the Secretary-General, https://treaties. un.org/pages/ParticipationStatus.aspx

- Where reference is made to the Hague Conference on Private International Law $(\mathrm{HccH})$, data were derived from http://www.hcch.net/index en.php?act=conventions.listing

- Where reference is made to the International Atomic Energy Agency (IAEA), date were derived from http://ola.iaea.org/ola/treaties/multi.html

- Where reference is made to the International Civil Aviation Organization (ICAO), data were derived from http://www.icao.int/secretariat/legal/pages/ treatycollection.aspx

- Where reference is made to the International Committee of the Red Cross (ICRC), data were derived from http://www.icrc.org/IHL.nsf/(SPF)/party_ main_treaties/\$File/IHL_and_other_related_Treaties.pdf

- Where reference is made to the International Labour Organization (ILO), data were derived from http://www.ilo.org/ilolex/english/convdispl.htm

1 Compiled by Dr. Karin Arts, Professor of International Law and Development at the International Institute of Social Studies of Erasmus University Rotterdam (ISS), based in The Hague, The Netherlands. 
- Where reference is made to the International Maritime Organization (IMO), data were derived from http://www.imo.org/About/Conventions/StatusOfConventions/Documents/Status\%20-\%202013.pdf

- Where reference is made to to the Secretariat of the Antarctic Treaty, data were derived from http://www.ats.aq/devAS/ats_parties. aspx?lang=e

- Where reference is made to the United Nations Educational, Scientific and Cultural Organization (UNESCO), data were derived from http://portal.unesco.org/en/ev.php-URL_ID=12025\&URL_DO=DO_ TOPIC\&URL_SECTION=-471.html

- Where reference is made to WIPO, data were derived from http:// www.wipo.int/treaties/en

- Reservations and declarations made upon signature or ratification are not included.

- $\quad$ Sig. = Signature; Cons. $=$ Consent to be bound; Eff. date = Effective date; E.i.f. = Entry into force; Min. age spec. - Minimum age specified; Rat. $=$ Ratification or accession .

\section{TABLE OF HEADINGS}

Antarctica

Commercial arbitration

Cultural matters

Cultural property

Development matters

Dispute settlement

Environment, fauna and flora

Family matters

Finance

Health

Human rights, including women and children

Humanitarian law in armed conflict Intellectual property

International crimes

International representation

International trade
Judicial and administrative cooperation

Labour

Narcotic drugs

Nationality and statelessness

Nuclear material

Outer space

Privileges and immunities

Refugees

Road traffic and transport

Sea

Sea traffic and transport

Social matters

Telecommunications

Treaties

Weapons 


\section{ANTARCTICA}

(Status as provided by the Secretariat of the Antarctic Treaty) Antarctic Treaty, Washington, 1959: see Vol. 6 p. 234.

\section{COMMERCIAL ARBITRATION}

\section{Convention on the Recognition and Enforcement of Foreign Arbitral Awards, 1958 \\ (Continued from Vol. 12 p. 234)}

$\begin{array}{rll}\text { State } & \text { Sig. } & \text { Cons. } \\ \text { Tajikistan } & & 14 \text { Aug } 2012\end{array}$

\section{CULTURAL MATTERS}

Agreement for Facilitating the International Circulation of Visual and Auditory Materials of an Educational, Scientific and Cultural Character, 1949: see Vol. 7 pp. 322-323.

Agreement on the Importation of Educational, Scientific and Cultural Materials, 1950: see Vol. 12 p. 234.

Convention concerning the International Exchange of Publications, 1958: see Vol. 6 p. 235.

Convention concerning the Exchange of Official Publications and Government Documents between States, 1958: see Vol. 6 p. 235.

International Agreement for the Establishment of the University for Peace, 1980: see Vol. 16 p. 157.

Regional Convention on the Recognition of Studies, Diploma's and Degrees in Higher Education in Asia and the Pacific, 1983: see Vol. 14 p. 227.

\section{CULTURAL PROPERTY}

Convention for the Protection of Cultural Property in the Event of Armed Conflict, 1954: see Vol. 13 p. 263. 
Protocol for the Protection of Cultural Property in the Event of Armed Conflict, 1954: see Vol. 13 p. 263.

Second Protocol for the Protection of Cultural Property in the Event of Armed Conflict, 1999: see Vol. 13 p. 263.

Convention for the Safeguarding of the Intangible Cultural Heritage, 2003: see Vol. 17 p. 164.

Convention on the Means of Prohibiting and Preventing the Illicit Import, Export and Transfer of Ownership of Cultural Property, 1970

(Continued from Vol. 12 p. 235)

(Status as provided by UNESCO)

$\begin{array}{rll}\text { State } & \text { Sig. } & \text { Cons. } \\ \text { Kazakhstan } & & 9 \text { Feb } 2012\end{array}$

Convention concerning the Protection of the

World Cultural and Natural Heritage, 1972

(Continued from Vol. 17 p. 164)

(Status as provided by UNESCO)

$\begin{array}{rll}\text { State } & \text { Sig. } & \text { Cons } \\ \text { Singapore } & & \text { 19 Jun } 2012\end{array}$

Convention on the Protection and Promotion of the

Diversity of Cultural Expressions, 2005

(Continued from Vol. 16 pp. 158)

(Status as provided by UNESCO)

$\begin{array}{rll}\text { State } & \text { Sig. } & \text { Cons. } \\ \text { Indonesia } & & \text { 12 Jan } 2012\end{array}$

\section{DEVELOPMENT MATTERS}

Charter of the Asian and Pacific Development Centre, 1982: see Vol. 7 pp. 323-324.

Agreement to Establish the South Centre, 1994: see Vol. 7 p. 324.

Amendments to the Charter of the Asian and Pacific Development Centre, 1998: see Vol. 10 p. 267. 
Multilateral Agreement for the Establishment of an International Think Tank for Landlocked Developing Countries, 2010

(Continued from Vol. 17 p. 165)

Entry into force: not yet

$\begin{array}{rll}\text { State } & \text { Sig. } & \text { Cons } \\ \text { Laos } & 27 \text { Sep 2011 } & \text { 26 Sep 2012 }\end{array}$

\section{DISPUTE SETTLEMENT}

Convention on the Settlement of Investment Disputes between States and

Nationals of Other States, 1965: see Vol. 11 p. 245.

Declarations Recognizing as Compulsory the Jurisdiction of the International Court of Justice under Article 36, paragraph 2, of the Statute of the Court

(Continued from Vol. 15 p. 159)

$\begin{array}{rll}\text { State } & \text { Sig. } & \text { Cons. } \\ \text { Timor Leste } & & 21 \text { Sep } 2012\end{array}$

\section{ENVIRONMENT, FAUNA AND FLORA}

International Convention for the Prevention of Pollution of the Sea by Oil, as amended, 1954: see Vol. 6 p. 238.

International Convention on Civil Liability for Oil Pollution Damage, 1969: see Vol. 15 p. 215.

International Convention Relating to Intervention on the High Seas in Cases of Oil Pollution Casualties, 1969: see Vol. 9 p. 284.

International Convention on the Establishment of an International Fund for Compensation for Oil Pollution Damage, 1971: see Vol. 12 p. 237.

Convention on the Prevention of Marine Pollution by Dumping of Wastes and Other Matter, 1972, as amended: see Vol. 7 p. 325.

Protocol Relating to Intervention on the High Seas in Cases of Pollution by Substances Other Than Oil, 1973: see Vol. 6 p. 239. 
Protocol to the 1969 International Convention on Civil Liability for Oil Pollution Damage, 1976: see Vol. 10 p. 269.

Protocol Relating to the 1973 International Convention for the Prevention of Pollution from Ships 1978, as amended: see Vol. 15 p. 225.

Protocol to amend the 1971 Convention on Wetlands of International Importance especially as Waterfowl Habitat, 1982: see Vol. 13 p. 265.

Convention for the Protection of the Ozone Layer, 1985: see Vol. 15 p. 215.

Protocol on Substances that Deplete the Ozone Layer, 1987: see Vol. 16 p. 161.

Amendments to Articles 6 and 7 of the 1971 Convention on Wetlands of International Importance especially as Waterfowl Habitat, 1987: see Vol. 13 p. 266.

Convention on the Control of Transboundary Movements of Hazardous Wastes and Their Disposal, 1989: see Vol. 16 p. 161.

International Convention on Oil Pollution Preparedness, Response, and Cooperation, 1990: see Vol. 12 p. 237.

Amendment to the Montreal Protocol, 1990: see Vol. 15 p. 216.

Framework Convention on Climate Change, 1992: see Vol. 13 p. 266.

Convention on Biological Diversity, 1992: see Vol. 14 p. 229.

Protocol to amend the 1969 International Convention on Civil Liability for Oil Pollution Damage, 1992: see Vol. 16 p. 161.

UN Convention to Combat Desertification in those Countries Experiencing Serious Drought and/or Desertification, Particularly in Africa, 1994: see Vol. 11 p. 247.

Amendment to the Convention on the Control of Transboundary Movements of Hazardous Wastes and Their Disposal, 1995: see Vol. 12 p. 238.

Protocol to the Framework Convention on Climate Change, 1997: see Vol. 16 p. 161. 
Rotterdam Convention on the Prior Informed Consent Procedure for Certain Hazardous Chemicals and Pesticides in International Trade, 1998: see Vol. 16 p. 162.

Cartagena Protocol on Biosafety to the Convention on Biological Diversity, 2000: see Vol. 15 p. 217.

Stockholm Convention on Persistent Organic Pollutants, 2001: see Vol. 15 pp. 217.

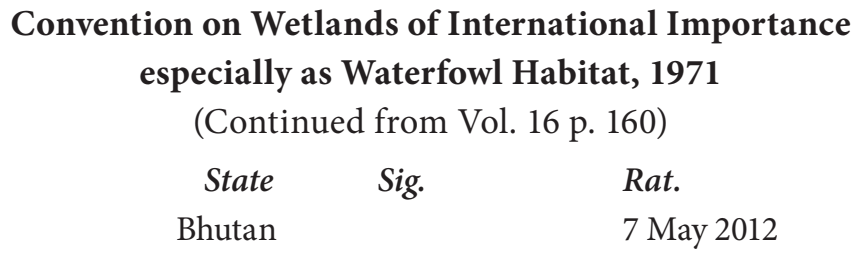

Amendment to the Montreal Protocol, 1992

(Continued from Vol. 17 p. 167)

State

Cons.

Nepal

18 May 2012

Amendment to the Montreal Protocol, 1997

(Continued from Vol. 17 p. 167)

State

Cons.

Myanmar

30 Jan 2012

Nepal

18 May 2012

Amendment to the Montreal Protocol, 1999

(Continued from Vol. 16 p. 162)

$\begin{aligned} \text { State } & \text { Cons. } \\ \text { Myanmar } & \text { 30 Jan } 2012 \\ \text { Nepal } & 18 \text { May } 2012\end{aligned}$




\section{International Convention on Civil Liability for \\ Bunker Oil Pollution Damage, 2001}

(Continued from Vol. 17 p. 167)

(Status as provided by IMO)

$\begin{array}{rll}\text { State } & \text { Cons. } & \text { E.i.f. } \\ \text { Iran } & 21 \text { Nov 2011 } & \text { 21 Feb } 2012\end{array}$

\section{FAMILY MATTERS}

Convention on the Recovery Abroad of Maintenance, 1956: see Vol. 11 p. 249.

Convention on the Law Applicable to Maintenance Obligations Towards Children, 1956: see Vol.6 p. 244.

Convention on the Conflicts of Law Relating to the Form of Testamentary Dispositions, 1961: see Vol. 7 p. 327.

Convention on Consent to Marriage, Minimum Age for Marriage and Registration of Marriages, 1962: see Vol. 8 p. 178.

Convention on the Law Applicable to Maintenance Obligations, 1973: see Vol. 6 p. 244.

Convention on Protection of Children and Co-operation in Respect of Intercountry Adoption, 1993: see Vol. 17 p. 168.

\section{FINANCE}

Agreement Establishing the Asian Development Bank, 1965: see Vol. 7 p. 327.

Convention Establishing the Multilateral Investment Guarantee Agency, 1988: see Vol. 12 p. 240.

\section{HEALTH}

Protocol Concerning the Office International d'Hygiène Publique, 1946: see Vol. 6 p. 245. 


\section{World Health Organization Framework Convention on Tobacco Control, 2003}

(Continued from Vol. 17 p. 168)

$\begin{array}{rll}\text { State } & \text { Sig. } & \text { Rat. } \\ \text { Uzbekistan } & & 15 \text { May } 2012\end{array}$

\section{HUMAN RIGHTS, INCLUDING WOMEN AND CHILDREN}

Convention on the Political Rights of Women, 1953: see Vol. 10 p. 273.

Convention on the Nationality of Married Women, 1957: see Vol. 10 p. 274.

Convention against Discrimination in Education, 1960: see Vol. 16 p. 164.

International Covenant on Economic, Social and Cultural Rights, 1966: see Vol. 14 p. 231.

International Covenant on Civil and Political Rights, 1966: see Vol. 16 p. 165.

International Convention on the Elimination of All Forms of Racial Discrimination, 1966: see Vol. 8 p. 179.

Optional Protocol to the International Covenant on Civil and Political Rights, 1966, see: Vol. 15 p. 219.

Convention on the Elimination of All Forms of Discrimination against Women, 1979: see Vol. 11 p. 250.

International Convention against Apartheid in Sports, 1985: see Vol. 6 p. 248.

Convention on the Rights of the Child, 1989: see Vol. 11 p. 251.

Optional Protocol to the Convention on the Elimination of All Forms of Discrimination against Women, 1999: see Vol. 17 p. 170.

Amendment to article 8 of the International Convention on the Elimination of All Forms of Racial Discrimination, 1992, see Vol. 12 p. 242. 
Convention Against Torture and Other Cruel, Inhuman or Degrading Treatment or Punishment, 1984

(Continued from Vol. 16 p. 165)

$\begin{array}{rll}\text { State } & \text { Sig. } & \text { Cons. } \\ \text { Laos } & 21 \text { Sep 2010 } & \text { 26 Sep 2012 }\end{array}$

Second Optional Protocol to the International Covenant on Civil and Political Rights, Aiming at the Abolition of the Death Penalty, 1989

(Continued from Vol. 16 p. 165)

State

Sig.

Cons.

Mongolia

13 Mar 2012

International Convention on the Protection of the Rights of All Migrant Workers and Members of Their Families, 1990

(Continued from Vol. 17 p. 170)

State

Sig.

Cons.

Indonesia

22 Sep 2004

31 May 2012

Optional Protocol to the Convention on the Rights of the Child on the Involvement of Children in Armed Conflict, 2000

(Continued from Vol. 16 p. 165)

$\begin{array}{rll}\text { State } & \text { Sig. } & \text { Cons. } \\ \text { Indonesia } & \text { 24 Sep 2001 } & \text { 24 Sep 2012 } \\ \text { Malaysia } & & \text { 12 Apr 2012 }\end{array}$

Optional Protocol to the Convention on the Rights of the Child on the Sale of Children, Child Prostitution and Child Pornography, 2000 (Continued from Vol. 17 p. 170)

$\begin{array}{rll}\text { State } & \text { Sig. } & \text { Cons. } \\ \text { Indonesia } & \text { 24 Sep 2001 } & \text { 24 Sep 2012 } \\ \text { Malaysia } & & \text { 12 Apr 2012 } \\ \text { Myanmar } & & \text { 16 Jan 2012 }\end{array}$

Optional Protocol to the Convention Against Torture and Other Cruel, Inhuman or Degrading Treatment or Punishment, 2002

(Continued from Vol. 14 p. 232)

$\begin{array}{rll}\text { State } & \text { Sig. } & \text { Cons. } \\ \text { Philippines } & & 17 \text { Apr } 2012\end{array}$


Convention on the Rights of Persons with Disabilities, 2008

(Continued from Vol. 17 p. 170).

$\begin{array}{rll}\text { State } & \text { Sig. } & \begin{array}{l}\text { Cons. } \\ \text { 18 Sep 2012 } \\ \text { Afghanistan }\end{array} \\ \text { Cambodia } & \text { 1 Oct 2007 } & \text { 20 Dec 2012 } \\ \text { Singapore } & \text { 30 Nov 2012 } & \end{array}$

Optional Protocol to the Convention on the Rights of Persons with Disabilities, 2008

(Continued from Vol. 16 p. 166)

State Sig. Cons.

Afghanistan 18 Sep 2012

International Convention for the Protection of All Persons from Enforced Disappearance, 2010

(Continued from Vol. 16 p. 166)

$\begin{array}{rlr}\text { State } & \text { Sig. } & \text { Cons. } \\ \text { Thailand } & 9 \text { Jan } 2012 & \end{array}$

\section{HUMANITARIAN LAW IN ARMED CONFLICT}

International Conventions for the Protection of Victims of War, I-IV, 1949: see Vol. 11 p. 252.

Protocol II Additional to the Geneva Conventions of 12 August 1949, and Relating to the Protection of Victims of Non-International Armed Conflicts, 1977, see: Vol. 12 p. 244.

Protocol III Additional to the Geneva Conventions of 12 August 1949, and Relating to the Adoption of an Additional Distinctive Emblem, 2005: see Vol. 17 p. 171.

\section{Protocol I Additional to the Geneva Conventions of 12 August 1949, and Relating to the Protection of Victims of I nternational Armed Conflicts, 1977}

(Continued from Vol. 15 p. 220)

$\begin{array}{rll}\text { State } & \text { Sig. } & \text { Cons. } \\ \text { Philippines } & 12 \text { Dec 1977 } & \text { 30 Mar } 2012\end{array}$




\section{INTELLECTUAL PROPERTY}

Convention for the Protection of Literary and Artistic Works, 1886 as amended 1979: see Vol. 12 p. 244.

Universal Copyright Convention, 1952: see Vol. 6 p. 251.

Protocols 1, 2 and 3 annexed to the Universal Copyright Convention, 1952: see Vol. 6 p. 251.

Nice Agreement Concerning the International Classification of Goods and Services for the Purposes of the Registration of Marks, 1957 as amended in 1979: see Vol. 13 p. 271.

Convention Establishing the World Intellectual Property Organization, 1967: see Vol. 12 p. 245.

Patent Cooperation Treaty, 1970 as amended in 1979 and modified in 1984 and 2001: see Vol. 15 p. 221.

Multilateral Convention for the Avoidance of Double Taxation of Copyright Royalties, 1979: see Vol. 6 p. 252.

Trademark Law Treaty, 1994: see Vol. 15 p. 222.

Patent Law Treaty, 2000: see Vol. 17 p. 172.

Convention for the Protection of Industrial Property, 1883 as amended 1979

(Continued from Vol. 11 p. 253)

(Status as provided by WIPO)

\begin{tabular}{|c|c|c|}
\hline State & Party & $\begin{array}{l}\text { Latest Act to which } \\
\text { State is Party }\end{array}$ \\
\hline & 17 Feb 2012 & Stockholm \\
\hline
\end{tabular}


Madrid Union Concerning the International Registration of Marks, including the Madrid Agreement 1891 as amended in 1979, and the Madrid Protocol 1989

(Continued from Vol. 16 p. 168)

(Status as provided by WIPO)

$\begin{array}{cll}\text { State } & \text { Party } & \begin{array}{l}\text { Latest Act to which } \\ \text { State is Party }\end{array} \\ \text { Laos } & \text { 14 Mar 2012 } & \text { Paris }\end{array}$

International Convention for the Protection of Performers, Producers of Phonograms and Broadcasting Organizations, 1961

(Continued from Vol. 15 p. 221)

(Status as provided by WIPO)

State

Cons. (deposit)

Kazakhstan

30 Mar 2012

Convention for the Protection of Producers of Phonograms against Unauthorized Duplication of Their Phonograms, 1971

(Continued from Vol. 12 p. 245)

(Status as provided by WIPO)

State Sig. Cons.

Tajikistan 16 Nov 2012

WIPO Performances and Phonograms Treaty, 1996

(Continued from Vol. 17 p. 172)

(Status as provided by WIPO)

State

Cons.

Malaysia

27 Dec 2012

WIPO Copyright Treaty, 1996

(Continued from Vol. 15, p. 222)

(Status as provided by WIPO)

State

Party

Malaysia

27 Dec 2012 
Singapore Treaty on the Law of Trademarks, 2006

(Continued from Vol. 17 p. 172)

(Status as provided by WIPO)

State

Cons.

Kazakhstan

5 Sep 2012

\section{INTERNATIONAL CRIMES}

Slavery Convention, 1926 as amended in 1953: see Vol. 15 p. 223.

Convention on the Prevention and Punishment of the Crime of Genocide, 1948: see Vol. 8 p. 182.

Supplementary Convention on the Abolition of Slavery, the Slave Trade, and Institutions and Practices Similar to Slavery, 1956: see Vol. 14 p. 236.

Convention on Offences and Certain Other Acts Committed on Board Aircraft, 1963: see Vol. 9 p. 289.

Convention on the Non-Applicability of Statutory Limitations to War Crimes and Crimes Against Humanity, 1968: see Vol. 6 p. 254.

Convention for the Suppression of Unlawful Seizure of Aircraft, 1970: see Vol. 8 p. 289.

Convention for the Suppression of Unlawful Acts Against the Safety of Civil Aviation, 1971: see Vol. 8 p. 290.

International Convention on the Suppression and Punishment of the Crime of Apartheid, 1973: see Vol. 7 p. 331.

Convention on the Prevention and Punishment of Crimes Against Internationally Protected Persons Including Diplomatic Agents, 1973: see Vol. 14 p. 236

International Convention Against the Taking of Hostages, 1979: see Vol. 16 p. 171.

Protocol for the Suppression of Unlawful Acts of Violence at Airports Serving International Civil Aviation, Supplementary to the Convention for 
the Suppression of Unlawful Acts Against the Safety of Civil Aviation, 1988, see Vol. 12 p. 247.

International Convention against the Recruitment, Use, Financing and Training of Mercenaries, 1989: see Vol. 11 p. 254.

Convention on the Marking of Plastic Explosives for the Purpose of Detection, 1991: see Vol. 15 p. 224.

Convention on the Safety of United Nations and Associated Personnel, 1994: see Vol. 11 p. 255.

International Convention for the Suppression of Terrorist Bombings, 1997: see Vol. 14 p. 236.

Statute of the International Criminal Court, 1998: see Vol. 16 p. 171.

International Convention for the Suppression of the Financing of Terrorism, 1999: see Vol. 15 p. 224.

Protocol against the Smuggling of Migrants by Land, Sea and Air, supplementing the United Nations Convention Against Transnational Organized Crime, 2000: see Vol. 15 p. 224.

Protocol against the Illicit Manufacturing of and Trafficking in Firearms, Their Parts and Components and Ammunition, supplementing the United Nations Convention Against Transnational Organized Crime, 2001: see Vol. 17 p. 174.

International Convention for the Suppression of Acts of Nuclear Terrorism, 2005: see Vol. 16 p. 172.

Convention for the Suppression of Unlawful Acts Against the Safety of Maritime Navigation, 1988

(Continued from Vol. 16 p. 171)

(Status as provided by IMO)

$\begin{array}{rll}\text { State } & \text { Sig. } & \text { Rat. } \\ \text { Laos } & \text { 20 Mar 2012 } & \text { 18 Jun 2012 }\end{array}$


Protocol for the Suppression of Unlawful Acts Against the Safety of Fixed Platforms Located on the Continental Shelf, 1988

(Continued from Vol. 16 p. 171)

(Status as provided by IMO)

$\begin{array}{clc}\text { State } & \text { Cons. (Deposited) } & \text { E.i.f. } \\ \text { Laos } & \text { 20 Mar } 2012 \quad \text { 18 Jun } 2012\end{array}$

\section{United Nations Convention Against \\ Transnational Organized Crime, 2000}

(Continued from Vol. 17 p. 174)

$\begin{array}{rll}\text { State } & \text { Sig. } & \text { Rat. } \\ \text { Vietnam } & \text { 13 Dec 2000 } & \text { 8 Jun 2012 }\end{array}$

Protocol to Prevent, Suppress and Punish Trafficking in Persons, Especially Women and Children, supplementing the United Nations

Convention Against Transnational Organized Crime, 2000

(Continued from Vol. 17 p. 175)

$\begin{array}{rll}\text { State } & \text { Sig. } & \text { Rat. } \\ \text { Vietnam } & & 8 \text { Jun } 2012\end{array}$

\section{United Nations Convention Against Corruption, 2003}

(Continued from Vol. 17 p. 175)

$\begin{array}{rll}\text { State } & \text { Sig. } & \text { Rat. } \\ \text { Myanmar } & 2 \text { Dec 2005 } & \text { 20 Dec } 2012\end{array}$

\section{INTERNATIONAL REPRESENTATION}

(see also: Privileges and Immunities)

Vienna Convention on the Representation of States in Their Relations with International Organizations of a Universal Character, 1975: see Vol. 6 p. 257.

\section{INTERNATIONAL TRADE}

Convention on the Limitation Period in the International Sale of Goods, 1974: see Vol. 6 p. 257. 
UN Convention on Contracts for the International Sale of Goods, 1980: see Vol. 14 p. 239.

UN Convention on the Liability of Operators of Transport Terminals in International Trade, 1991: see Vol. 6 p. 257.

United Nations Convention on the Use of Electronic Communications in International Contracts, 2005: see Vol. 16 p. 173.

Convention on Transit Trade of Land-locked States, 1965: see Vol. 17 p. 176.

\section{JUDICIAL AND ADMINISTRATIVE COOPERATION}

Convention on Civil Procedure, 1954: see Vol. 6 p. 258.

Convention on the Service Abroad of Judicial and Extrajudicial Documents in Civil or Commercial Matters, 1965: see Vol. 9 p. 291.

Convention on the Taking of Evidence Abroad in Civil or Commercial Matters, 1970: see Vol. 16 p. 173.

\section{Convention Abolishing the Requirement of Legalisation for Foreign Public Documents, 1961}

(Continued from Vol. 17 p. 176)

(Status as provided by the $\mathrm{HccH}$ )

$\begin{array}{rll}\text { State } & \text { Cons. } & \text { E.i.f. } \\ \text { Uzbekistan } & \text { 25 Jul 2011 } & \text { 15 Apr 2012 }\end{array}$

\section{LABOUR}

Forced Labour Convention, 1930 (ILO Conv. 29): see Vol. 15 p. 226.

Freedom of Association and Protection of the Right to Organise Convention, 1948 (ILO Conv. 87): see Vol. 15 p. 226.

Right to Organise and Collective Bargaining Convention, 1949 (ILO Conv. 98): see Vol. 15 p. 226.

Abolition of Forced Labour Convention, 1957 (ILO Conv. 105): see Vol. 12 p. 250. 
Equal Remuneration Convention, 1951 (ILO Conv. 100): see Vol. 14 p. 240.

Discrimination (Employment and Occupation) Convention, 1958 (ILO Conv. 111): see Vol. 12 p. 250.

Worst Forms of Child Labour Convention, 1999 (ILO Conv. 182): see Vol. 16 p. 174.

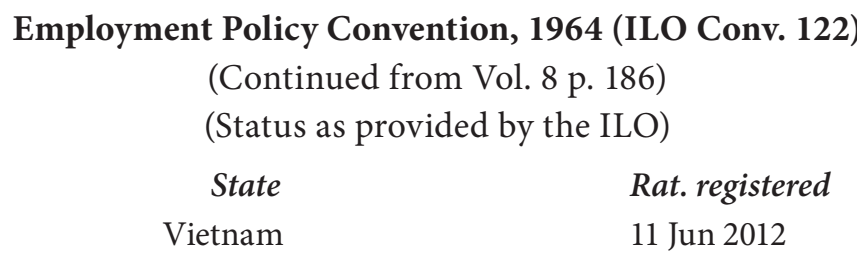

Minimum Age Convention, 1973 (ILO Conv. 138)

(Continued from Vol. 17 p. 177)

(Status as provided by the ILO)

State Rat. registered Min. age spec.

Turkmenistan 27 Mar $2012 \quad 16$

Promotional Framework for Occupational Safety and

Health Convention (ILO Conv. 187), 2006

(Continued from Vol. 16 p. 175)

(Status as provided by the ILO)

$\begin{aligned} \text { State } & \text { Rat. registered } \\ \text { Malaysia } & 7 \text { Jun } 2012 \\ \text { Singapore } & 11 \text { Jun } 2012\end{aligned}$

\section{NARCOTIC DRUGS}

Protocol Amending the Agreements, Conventions and Protocols on Narcotic Drugs, concluded at The Hague on 23 January 1912, at Geneva on 11 February 1925 and 19 February 1925 and 13 July 1931, at Bangkok on 27 November 1931 and at Geneva on 26 June 1936, 1946: see Vol. 6 p. 261. 
Agreement Concerning the Suppression of the Manufacture of, Internal Trade in, and Use of, Prepared Opium and amended by Protocol, 1925, amended 1946: see Vol. 6 p. 261.

International Opium Convention, 1925, amended by Protocol 1946: see Vol. 7 p. 334.

Agreement Concerning the Suppression of Opium Smoking, 1931, amended by Protocol, 1946: see Vol. 6 p. 261.

Convention for Limiting the Manufacture and Regulating the Distribution of Narcotic Drugs, 1931, and amended by Protocol, 1946: see Vol. 7 p. 334.

Protocol bringing under International Control Drugs outside the Scope of the Convention of 1931, as amended by the Protocol of 1946: see Vol. 6 p. 262.

Convention for the Suppression of the Illicit Traffic in Dangerous Drugs, 1936, amended 1946: see Vol. 6 p. 262.

Protocol for Limiting and Regulating the Cultivation of the Poppy Plant, the Production of, International and Wholesale Trade in, and Use of Opium, 1953: see Vol. 6 p. 262.

Single Convention on Narcotic Drugs, 1961: see Vol. 13 p. 276.

Convention on Psychotropic Substances, 1971: see Vol. 13 p. 276.

Single Convention on Narcotic Drugs, 1961, as Amended by Protocol 1972: see Vol. 15 p. 227.

Protocol amending the Single Convention on Narcotic Drugs, 1972: see Vol. 15 p. 227.

United Nations Convention Against Illicit Traffic in Narcotic Drugs and Psychotropic Substances, 1988: see Vol. 13 p. 276. 


\section{NATIONALITY AND STATELESSNESS}

Convention relating to the Status of Stateless Persons, 1954: see Vol. 17 p. 178.

Convention on the Physical Protection of Nuclear Material, 1980: see Vol. 12 p. 252.

Optional Protocol to the Vienna Convention on Diplomatic Relations concerning Acquisition of Nationality, 1961: see Vol. 6 p. 265.

Optional Protocol to the Vienna Convention on Consular Relations concerning Acquisition of Nationality, 1963: see Vol. 8 p. 187.

\section{NUCLEAR MATERIAL}

Convention on Civil Liability for Nuclear Damage, 1963: see Vol. 17 p. 179.

Joint Protocol Relating to the Application of the Vienna Convention (and the Paris Convention on Third Party Liability in the Field of Nuclear Energy), 1980: see Vol. 6 p. 265.

Convention on Assistance in the Case of a Nuclear Accident or Radiological Emergency, 1986: see Vol. 17 p. 179.

Convention on Supplementary Compensation for Nuclear Damage, 1997: see Vol. 16 p. 265.

Joint Convention on the Safety of Spent Fuel Management and on the Safety of Radioactive Waste Management, 1997: see Vol. 17 p. 180).

Protocol to Amend the 1963 Convention on Civil Liability for Nuclear Damage, 1997: see Vol. 17 p. 180.

\section{Convention on the Physical Protection of Nuclear Material, 1980}

(Continued and corrected from Vol. 12 p. 252) (Status as provided by IAEA)

$\begin{array}{rrr}\text { State } & \text { Sig. } & \text { Cons. (deposit) } \\ \text { Laos } & & \text { 29 Sep 2010 } \\ \text { Vietnam } & \text { 4 Oct 2012 }\end{array}$


Convention on Early Notification of a Nuclear Accident, 1986

(Continued from Vol. 17 p. 179)

(Status as provided by IAEA)

$\begin{array}{rll}\text { State } & \text { Sig. } & \text { Cons. (deposit) } \\ \text { Cambodia } & & 5 \text { Apr } 2012\end{array}$

Convention on Nuclear Safety, 1994

(Continued from Vol. 12 p. 252)

(Status as provided by IAEA)

State Sig. Cons. (deposit)

Cambodia 5 Apr 2012

Amendment to the 1980 Convention on the

Physical Protection of Nuclear Material, 2005

(Continued from Vol. 17 p. 180)

(Status as provided by IAEA)

State Sig. Cons. (deposit)

Vietnam 3 Nov 2012

\section{OUTER SPACE}

Treaty on Principles Governing the Activities of the States in the Exploration and Use of Outer Space, Including the Moon and Other Celestial Bodies, 1967: see Vol. 16 p. 178.

Agreement governing the Activities of States on the Moon and other Celestial Bodies, 1979: see Vol. 10 p. 284.

Convention on Registration of Objects launched into Outer Space, 1974: see Vol. 15 p. 229.

\section{PRIVILEGES AND IMMUNITIES}

Convention on the Privileges and Immunities of the United Nations, 1946: see Vol. 14 p. 242.

Convention on the Privileges and Immunities of the Specialized Agencies, 1947: see Vol. 7 p. 338. 
Vienna Convention on Diplomatic Relations, 1961: see Vol. 13 p. 277.

Optional Protocol to the Vienna Convention on Diplomatic Relations concerning the Compulsory Settlement of Disputes, 1961: see Vol. 6 p. 269.

Vienna Convention on Consular Relations, 1963: see Vol. 13 p. 278.

Optional Protocol to the Vienna Convention on Consular Relations concerning the Compulsory Settlement of Disputes, 1963: see Vol. 6 p. 269.

Convention on Special Missions, 1969: see Vol. 6 p. 269.

Optional Protocol to the Convention on Special Missions concerning the Compulsory Settlement of Disputes, 1969: see Vol. 6 p. 269.

United Nations Convention on Jurisdictional Immunities of States and Their Property, 2004: see Vol. 15 p. 230.

\section{REFUGEES}

Convention relating to the Status of Refugees, 1951: see Vol. 12 p. 254.

Protocol relating to the Status of Refugees, 1967: see Vol. 12 p. 254.

\section{ROAD TRAFFIC AND TRANSPORT}

Convention on Road Traffic, 1968: see Vol. 12 p. 254.

Convention on Road Signs and Signals, 1968: see Vol. 7 p. 338.

\section{SEA}

Convention on the Territorial Sea and the Contiguous Zone, 1958: see Vol. 6 p. 271.

Convention on the High Seas, 1958: see Vol. 7 p. 339.

Convention on Fishing and Conservation of the Living Resources of the High Seas, 1958: see Vol. 6 p. 271.

Convention on the Continental Shelf, 1958: see Vol. 6 p. 271. 
Optional Protocol of Signature concerning the Compulsory Settlement of Disputes, 1958: see Vol. 6 p. 272.

Agreement relating to the Implementation of Part XI of the United Nations Convention on the Law of the Sea of 10 December 1982, 1994: see Vol. 17 p. 182.

Agreement for the Implementation of the Provisions of the United Nations Convention on the Law of the Sea (...) Relating to the Conservation and Management of Straddling Fish Stocks and Highly Migratory Fish Stocks, 1995: see Vol. 16 p. 230.

\section{United Nations Convention on the Law of the Sea, 1982}

(Continued from Vol. 10 p. 285)

$\begin{array}{rll}\text { State } & \text { Sig. } & \text { Cons. } \\ \text { Thailand } & 10 \text { Dec } 1982 & \text { 15 May 2011 }\end{array}$

\section{SEA TRAFFIC AND TRANSPORT}

Convention Regarding the Measurement and Registration of Vessels employed in Inland Navigation, 1956: see Vol. 6 p. 273.

International Convention for the Safety of Life at Sea, 1960: see Vol. 6 p. 273.

Convention on Facilitation of International Maritime Traffic, 1965 as amended: see Vol. 12 p. 255.

International Convention on Load Lines, 1966: see Vol. 15 p. 230.

International Convention on Tonnage Measurement of Ships, 1969: see Vol. 15 p. 231.

Special Trade Passenger Ships Agreement, 1971: see Vol. 6 p. 275.

International Convention for Safe Containers, as amended 1972: see Vol. 10 p. 286.

Convention on the International Regulations for Preventing Collisions at Sea, 1972: see Vol. 15 p. 231. 
Protocol on Space Requirements for Special Trade Passenger Ships, 1973: see Vol. 6 p. 275.

Convention on a Code of Conduct for Liner Conferences, 1974: see Vol. 6 p. 276.

International Convention for the Safety of Life at Sea, 1974: see Vol. 15 p. 231.

Protocol Relating to the International Convention for the Safety of Life at Sea, 1974 as amended 1978: see Vol. 12 p. 256.

UN Convention on the Carriage of Goods by Sea, 1978: see Vol. 6 p. 276.

\section{Protocol Relating to the International Convention on Load Lines, 1988}

(Continued from Vol. 12 p. 256)

(Status as provided by IMO)

$\begin{array}{rlr}\text { State } & \text { Cons. (dep.) } & \text { E.i.f. } \\ \text { Malaysia } & 11 \text { Nov } 2011 & \end{array}$

Protocol Relating to the International Convention for the
Safety of Life at Sea, $\mathbf{1 9 8 8}$
(Continued from Vol. 14 p. 231)
(Status as provided by IMO)
State $\quad$ Cons. (dep.) E.i.f.
Malaysia $\quad 11$ Nov 2011

\section{SOCIAL MATTERS}

International Agreement for the Suppression of the White Slave Traffic, 1904, amended by Protocol 1949: see Vol. 6 p. 278.

International Convention for the Suppression of the White Slave Traffic, 1910, amended by Protocol 1949: see Vol. 6 p. 278.

Agreement for the Suppression of the Circulation of Obscene Publications, 1910, amended by Protocol 1949: see Vol. 6 p. 278. 
International Convention for the Suppression of the Traffic in Women and Children, 1921: see Vol. 6 p. 277.

Convention for the Suppression of the Traffic in Women and Children, 1921, amended by Protocol in 1947: see Vol. 6 p. 277.

International Convention for the Suppression of the Circulation of and Traffic in Obscene Publications, 1923: see Vol. 6 p. 277.

Convention for the Suppression of the Circulation of, and Traffic in, Obscene Publications, 1923, amended by Protocol in 1947: see Vol. 6 p. 277.

International Convention for the Suppression of the Traffic in Women of Full Age, 1933: see Vol. 6 p. 277.

Convention for the Suppression of the Traffic in Women of Full Age, 1933, amended by Protocol, 1947: see Vol. 6 p. 277.

Convention for the Suppression of the Traffic in Persons and of the Exploitation of the Prostitution of Others, 1950: see Vol. 12 p. 257.

Final Protocol to the Convention for the Suppression of the Traffic in Persons and of the Exploitation of the Prostitution of Others, 1950: see Vol. 12 p. 257.

\section{TELECOMMUNICATIONS}

Constitution of the Asia-Pacific Telecommunity, 1976: see Vol. 13 p. 280.

Convention on the International Maritime Satellite Organization (INMARSAT), 1976 (as amended): see Vol. 8 p. 193.

Amendment to Article 11, Paragraph 2(a), of the Constitution of the AsiaPacific Telecommunity, 1981: see Vol. 8 p. 193.

Amendments to articles 3(5) and 9(8) of the Constitution of the Asia-Pacific Telecommunity, 1991: see Vol. 9 p. 298.

Agreement establishing the Asia-Pacific Institute for Broadcasting Development, 1977: see Vol. 10 p. 287. 
Tampere Convention on the Provision of Telecommunication Resources for Disaster Mitigation and Relief Operations, 1998: see Vol. 15 p. 232.

Amendments to the Agreement establishing the Asia-Pacific Institute for Broadcasting Development, 1999: see Vol. 10 p. 288.

Amendments to the Constitution of the Asia-Pacific Telecommunity, 2002: see Vol. 13 p. 280.

\section{TREATIES}

Vienna Convention on the Law of Treaties, 1969: see Vol. 12 p. 258.

Vienna Convention on the Law of Treaties Between States and International Organizations or Between International Organizations, 1986: see Vol. 6 p. 280.

\section{WEAPONS}

Protocol for the Prohibition of the Use in War of Asphyxiating, Poisonous or other Gases, and of Bacteriological Warfare, 1925: see Vol. 6 p. 281.

Treaty Banning Nuclear Weapon Tests in the Atmosphere, in Outer Space and Under Water, 1963: see Vol. 6 p. 281.

Treaty on the Non-Proliferation of Nuclear Weapons, 1968: see Vol. 11 p. 262.

Treaty on the Prohibition of the Emplacement of Nuclear Weapons and Other Weapons of Mass Destruction on the Sea-Bed and the Ocean Floor and in the Subsoil Thereof, 1971: see Vol. 6 p. 282.

Convention on the Prohibition of the Development, Production and Stockpiling of Bacteriological (Biological) and Toxin Weapons and on Their Destruction, 1972: see Vol. 13 p. 281.

Convention on the Prohibition of Military or any other Hostile Use of Environmental Modification Techniques, 1976: see Vol. 12 p. 258. 
Convention on Prohibitions or Restrictions on the Use of Certain Conventional Weapons which may be Deemed Excessively Injurious or to have Indiscriminate Effects, and Protocols, 1980: see Vol. 11 p. 263.

Convention on the Prohibition of the Development, Production, Stockpiling and Use of Chemical Weapons and on Their Destruction, 1993: see Vol. 12 p. 259.

Comprehensive Nuclear Test Ban Treaty, 1996: see Vol. 12 p. 259.

Convention on the Prohibition of the Use, Stockpiling, Production and Transfer of Anti-Personnel Mines and on Their Destruction, 1997: see Vol. 13 p. 281.

Amendment of Article 1 of the 1980 Convention on Prohibitions or Restrictions on the Use of Certain Conventional Weapons which may be Deemed Excessively Injurious or to have Indiscriminate Effects, 2001: see Vol. 12 p. 259.

Convention on Cluster Munitions, 2008: see Vol. 16 p. 259. 